\title{
Ethics and Procurement Performance of Humanitarian Organizations in Kenya
}

\author{
Makali Juliet Maria, Wainaina Githii, Ogoro Thomas Ombati \\ School of Business, Department of Management Science, University of Nairobi, Nairobi, Kenya \\ Email: healymaria477@gmail.com,wainaina.githii@uonbi.ac.ke,thomasombati@uonbi.ac.ke
}

How to cite this paper: Maria, M.J., Githii, W. and Ombati, O.T. (2018) Ethics and Procurement Performance of Humanitarian Organizations in Kenya. American Journal of Industrial and Business Management, 8, 833-849.

https://doi.org/10.4236/ajibm.2018.84058

Received: February 25, 2018

Accepted: April 21, 2018

Published: April 24, 2018

Copyright $\odot 2018$ by authors and Scientific Research Publishing Inc. This work is licensed under the Creative Commons Attribution International License (CC BY 4.0).

http://creativecommons.org/licenses/by/4.0/

\begin{abstract}
The purpose of this study is to establish the relationship between ethics and procurement performance of humanitarian organizations in Kenya. The study draws on data from 70 humanitarian organizations and makes use of multiple regression models to deduce the relationship. Findings show that humanitarian organizations in Kenya follow procurement ethics code. Further work is needed to examine the relationship between ethics and procurement performance of humanitarian organizations in Africa as this would give a wide range of conclusions and recommendations. Future studies could relate the independent variables used in this study to cost reduction strategy instead of agility strategy addressed herein. The results indicate that ethics is shaping up today's humanitarian picture by ensuring that donors and other interested parties have confidence in supporting the humanitarian cause. This is the first paper to systematically analyze relationship between ethics and procurement performance of humanitarian organizations in Kenya.
\end{abstract}

\section{Keywords}

Ethics, Procurement Performance, Humanitarian Organizations

\section{Introduction}

Every year, there are, on average, 500 disasters that kill up to 75,000 people and affect about 200 million people world over [1]. For instance, in 2011 natural disasters killed $30+$ million people and were injurious to $244+$ million victims worldwide [2]. Indeed, humanitarian organizations across the globe have come together to provide relief aid to billions of suffering people. According to the global humanitarian assistance survey, humanitarian assistance cost 537 million US dollars and Kenya was the $8^{\text {th }}$ largest recipient of official humanitarian assistance in the year 2011. World Health Organization (WHO) and UN (FAO) en- 
sure that food is made available to those who might starve. Similarly, the United Nations High Commissioner for Refugees (UNHCR) and International Organization for Migration (IOM) set up camps and other facilities for those who are forced to leave their homes in case of a disaster. WHO protects those displaced by natural and man-made disasters whilst the United Nations Children's' Fund (UNICEF) and other aid of bodies like Save the Children provide education for children who have been displaced by calamity. According to the Kenyan Non-Governmental Organization (NGO) Coordination Board, in 2015, there were 70 humanitarian organizations operating in Kenya. Humanitarian organizations are divided into four categories: government-sponsored humanitarian organizations like Kenya Red Cross Society (KRCS), privately-sponsored and registered as NGO's with the NGO Council, like Oxfam and Save the Children, faith-based humanitarian organizations established by churches and mosques like Catholic Relief Service and Caritas Internationalis and lastly organizations affiliated to the United Nations Organization (UNO) like the United Nations Development Programme (UNDP) and WHO [3]. Governments hold power due to control they have over political and economic conditions and directly affect the supply chain processes operating within their jurisdictions and Kenya Government is no exception.

The objective of any relief chain is to provide humanitarian assistance in the form of food, water, medicine, shelter and supplies to areas affected by large-scale emergencies [4]. According to [5], humanitarian supply chains must be fast and agile. Procurement in humanitarian operations faces different challenges than those experienced in the private sector. The nature of most disasters demands that the supply chain be designed and deployed immediately albeit with limited resources, inadequate knowledge of needs in the field and a complex group of suppliers [6]. Generally speaking, adopting ethics principles drives humanitarian supply chain management performance. However, how ethical principles have been adopted and applied to improve operations in the Kenyan context is not known and hence there is the extant study.

\section{Literature Review}

Procurement performance is a measure of extent to which the procurement function is able to reach the objectives and goals with minimum costs [7]. The measure provides a basis for effective control and stewardship of resources and reveals the value of the procurement function. Well stipulated procurement performance objectives can fast track an organization's change process and improve its viability. Procurement performance, according to [8], is a key driver in improving superiority of services while its absence or inappropriate application can act as an obstruction to change and may lead to decline of the purchasing function. Most organizations have no performance measures in place for assessing procurement efficiency and effectiveness [9]. In addition, most developing countries face a setback of hasty changes in procurement requirements. These 
changes impact how procurement function delivers interior and exterior processes and procedures in order to realize objectives. Humanitarians are beginning to heed to lessons learnt from previous disasters and realizing that they have to work continuously; not only during disasters but also between disasters [1]. Effective performance measurement systems would assist relief chain practitioners in decision making, help improve the effectiveness and efficiency of relief operations and demonstrate the performance of the relief chain, thereby increasing the transparency and accountability of response to disaster. Since relief efforts generally operate on limited funds, there is also the need to demonstrate cost effectiveness by adopting low cost inventory management systems [4].

According to [10], ethics refer to principles of conduct governing an individual or group; concerned with what is right or wrong, good or bad. Ethical behaviour in procurement performance is of particular relevance today because of stakeholder pressure [11]. This has led to the call for adoption of ethics humanitarian procurement as organizations realise it could lead to better operational performance [12]. The role supply chain managers entail "organizing the optimal flow of high-quality, value-for-money materials or components from a suitable set of innovative suppliers" [13] and are exposed to a range of selling techniques, some of which are less ethical than others [14].

Supply chain managers routinely encounter situations that put ethics to test. Ethical concerns are addressed by credible bodies to ensure that organizations incorporate ethics in procurement. For instance, World Responsible Apparel Production (WRAP) is an independent, non-profit organization dedicated to the certification of lawful, humane and ethical manufacturing throughout the world. Others include International Labour Organization (ILO) Conventions and UN Declaration of Human Rights. Supply management procurement ethics involves: impartiality in supplier selection; personalities not improperly influencing the buying decision; providing prompt and honest responses to customer inquiries and requests; provision of adequate knowledge or skills to individuals so that they competently perform assigned duties; providing products and services of the highest quality in the eyes of the internal customers; decline to receive gifts or entertainment that could influence or appear to influence purchasing decisions; and identification of customer's needs and corresponding products and services that meet those needs [15].

It has been argued by [16] that sensitive practices involving standards of conduct in procurement include avoidance of unethical supply management behavior like acceptance of gifts, competitive bidding, negotiation and everyday dealings with vendors. The subject of supply management ethics has received insufficient coverage in the past [17]. A recent study of supply management practices rated ethics to be the number one issue facing supply managers [18]. Many enterprises around the world are unaware of how effective ethics and compliance programs can help them avoid costly recalls and brand damage that results from supply chain ethics and scandals [19]. Despite the general humani- 
tarian procurement attracting interest from many researchers, the import of ethics on procurement performance has insufficiently been addressed [20]. As a result, humanitarian supply chains lag behind private sector [1] supply chains efficiency-wise. Also, modern donors are more aware of expenditures and as such humanitarian organizations are under greater scrutiny. There is observed need to adopt right strategies that will make supply chains agile, adaptable and aligned.

There is a positive relationship between well instituted ethical principles and supply chain improvement in oil marketing organizations [21]. However, conducting this type of studies is challenging because participants are usually unwilling to disclose confidential information on ethics as this could be held against them by the organization based on breaching the confidentiality policy. Studies on ethics have been carried out in other contexts and outside Kenya although not in humanitarian organizations. This study sought to answer the following research questions: what is the extent to which ethics is practiced by humanitarian organizations in Kenya? What is the impact of procurement performance of humanitarian supply chains in Kenya? What are the challenges faced in implementing ethics by humanitarian organizations in Kenya? The general goals within organizations operating in humanitarian supply chains are perceived to be focused upon maximizing effectiveness in delivery of aid to recipients. There are efficiency issues which are affected by ethics and operational strategies of the organization [22]. The manner in which an entity handles ethical consideration influences donors' perception and level of funding provided [23], meaning that donor support for a humanitarian organization is tied to adoption of ethical practices [24].

According to [25], the study of ethical behavior in buyer-supplier relationship chain is emergent and contemporary. Unethical supply management behaviour is common in the areas like; competitive bidding, negotiation, giving preference to a supplier [16], conflict of interest and confidentiality. Ethics is not only included in the humanitarian organizations' values and strategies, but also in relationships and collaboration with suppliers [26]. In order to achieve mutual ethical behaviour and values among actors involved in the supply chain, humanitarian organizations implement Codes of Conduct. Usually, unethical behaviour in supplier networks poses a constant risk for the organizations' credibility and threatens the flow of incoming donations [26]. Supply and procurement managers are exposed to ethical challenges during day-to-day task execution and decision making [14]. The next subsection discusses the theories underpinning ethics in procurement which include; competitive bidding, gifts, conflict of interest, negotiation, confidentiality, reciprocity, sharp practices and personal buying (in italics below).

\section{Unethical Supply Management Behaviors}

Competitive bidding is a process whereby suppliers are asked to make bids in terms of pricing before the buyer chooses the best offer. Ethics demand that 
firms ensure equity and fairness by way of a bidding process so that potential suppliers are identified and invited to participate [27]. However, according to [28], in cases of disasters of a big magnitude, tendering process may not be strictly adhered to. Similarly, formal bidding cannot be used for supplies such as in high emergency procurement of aid materials. In this case, informal competition may be achieved through price quotations from several national suppliers provided that the price, quality, time of delivery, after-sales-service and other relevant features of the contract are competitive by national standards [29]. World Bank identifies two ethical violations in regards to competitive bidding; bid rigging and bid collusion. Humanitarian organizations like International Federation for Red Cross (IFRS) (2011) demand that all potential suppliers commit to set standards of integrity. Giving gifts and offers of hospitality are among the common courtesies of business dealings. The challenge to procurement professionals is in deciding when such practices amount to inducement for favourable sourcing or contract award decisions, information disclosure or other favourable treatment [10]. Purchasing Management Association of Canada (PMAC) codes of conduct discourages acceptance of gratuities beyond token gifts of nominal value [30].

Conflict of interest is an ethical only if the judgement of procurement officer is compromised so as to take decisions that favour a particular bidder to the detriment of the others. A study carried out by [31] explains that conflict of interest exists if the tenderer is an employee of the organization, or professionally relates with the person, awarding the tender. However, this is different from negotiation inherent in procurement processes. Unethical negotiation actions condemned by the code of ethics of ISM and PMCA include: a purchaser falsely claiming to have received a quotation; misleading the sales representative through make believe telephone chats; providing untrue information about bids from competitors to sales representative [30] [32].

Reciprocity is the practice of awarding tenders to known customers or using a tender to entice a supplier to become a customer. By locking out competitor suppliers, the buying firm denies itself the economies of competition hence realization performance objectives [33]. Next unethical procurement behaviour entails sharp practices, meaning any misrepresentation by a buyer. This includes: gaining information unfairly through deception; knowingly and unduly putting pressure to suppliers with liquidity problems so as to get low bids and in the process getting the supplier out of business [33]. Personal buying entails use of a buying organisation's name to procure goods and services for individual employees. Trade diversion laws prohibit competing personal vis-à-vis organization conflict of interest. Personal buying is a gray area to many a purchasing department because it could be viewed as a fringe benefit and hence it should be flatly prohibited from practice [30].

Confidentiality ensures that concerned organisations conceal private information such as bids, contract terms and conditions from unauthorized individuals 
or entities.

\section{Performance Measurement Constructs}

Organizations involved in disaster management consider supply chains performance vital to their existence [1]. This could be explained by changes such as increasing number of entities competing for scarce resources as well as the reality that the modern donor is more informed than the traditional donor and has set higher accountability standards [4].

Although there is an increasing interest in performance measurement of non-profit organizations, few attempts have been made to provide these organizations with a performance measurement framework [34]. In the humanitarian sector, performance is hard to measure, as demand and supply is not directly regulated through price [1].

Procurement performance involves two main aspects: effectiveness and efficiency. Procurement effectiveness is the extent to which the previously stated goals and objectives are being met while procurement efficiency is the relationship between planned and actual resources required to realize the established goals and objectives and related activities. However, the most important driver of procurement performance is supplier performance. Effectiveness in procurement considers indicators such supplier quality, delivery management, flexibility of suppliers, material quality defects, supplier profile, inventory incoming on-time, order cycle time and documentation.

Effective performance measurement can help non-profit managers make better decisions, improve performance and provide accountability. It also helps allocate resources more effectively, evaluate the efficacy of alternative approaches and gain greater control over operations, even when allowing increased flexibility at operating level [35]. Ethics in procurement performance aims to achieve a number of objectives; transparency, which is the ability to understand how processes interact within the supply chain in order to improve performance, helps to answer questions of efficiency: are we doing it well? [6], for instance, competitive bidding is a transparent process that invites all potential suppliers to a bid [27]; reputation, which means the evaluation of a firm by its stakeholders in terms of their effect, esteem and knowledge [36], unethical procurement practices in supply networks endanger the credibility of humanitarian organizations [26] like, offer of gifts by donors with a motive of giving bribes results in negative publicity which adversely affects the procurement performance; accountability which identifies who is responsible for the actions within the procurement process and how well the actions are performed, and to improve on accountability, conflict of interest aims at ensuring that assigning responsibility is not compromised on the basis of professional relationship with partners [30]; improved response time where in humanitarian operation, improved response time translates into speed and accuracy in delivering aid to the affected areas, a successful humanitarian operation mitigates the urgent needs of a population with a sus- 
tainable reduction of their vulnerability in the shortest amount of time [6]; ethical reciprocity enables the supplier and buyer obtain a great understanding of mutual problems thus increasing goodwill, whereas unethical reciprocity enables buyers use buying decisions to inappropriately enhance a sales opportunity [10]; unethical sharp practices encourage buying through deception and taking unfair advantage over suppliers when buying; ethical personal buying aims at ensuring employees enjoy fringe benefits like work safety gear [30], as unethical personal buying is a misuse of trade discounts [14], and lastly, confidentiality aims at ensuring that confidential and propriety information like bids, contract terms are not exposed to unauthorized persons.

\section{Conceptual Framework}

There is a positive relationship between excellence in operations and ethics. Excellence in companies implies a strong presence of ethical behavior [37]. Ethical codes of conduct are developed based on operational efficiency, are profession related, cater for public interest, and should support self-regulation [38]. Indeed, the more ethical the practices in an organization are, the better the effectiveness of the procurement process [39]. Transparency, fair treatment in bidding and award of tenders; accountability and responsible purchasing and supply have a positive implication on procurement processes in any organization and may result into increased performance and delivery. Unethical practices among procurement officers in public procurement negatively affects procurement processes and hence the overall procurement performance [40]. However, literature review shows that previous studies have not been able to link ethics with procurement performance of humanitarian organizations in Kenya. The conceptual framework, Figure 1, ethical dilemmas are treated as independent variables that influence the performance of humanitarian organizations in Kenya. They should therefore be implemented in order to win the confidence and trust of donors, governments, corporate entities and all other stakeholders who donate towards humanitarian assistance.

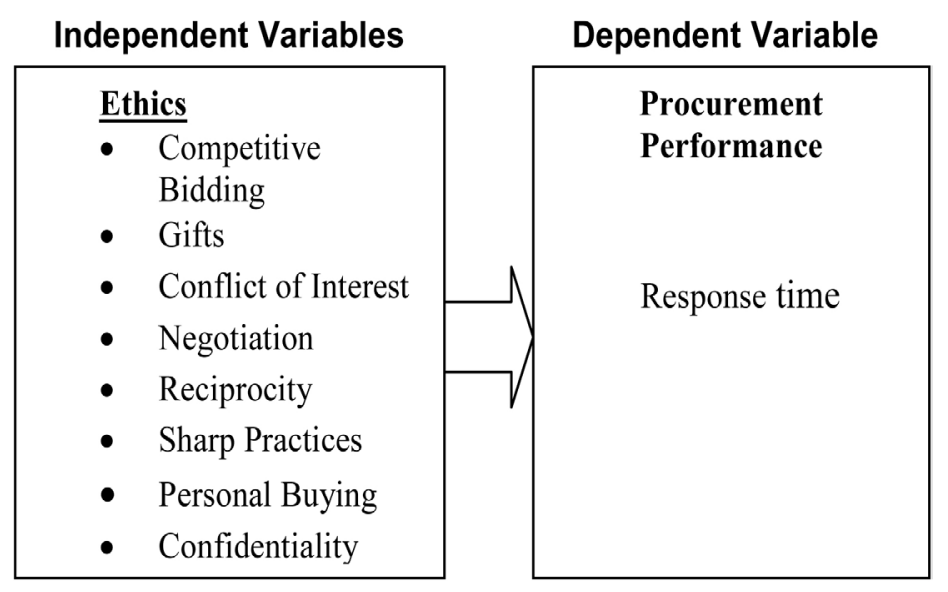

Figure 1. Ethics and procurement performance. 


\section{Methodology}

Data was collected from all the 70 humanitarian organizations in Kenya, registered with the NGO Coordination Board. This study did not require sampling because the total population of registered humanitarian organizations in Kenya in 2016 were about 70 (NGO Coordination Board, 2016) so a survey was used. A total of 70 questionnaires were issued for the 70 registered humanitarian organizations in Kenya and a total of 51 were returned. This represented a response rate of $73 \%$, which is considered adequate for the research. The demographic characteristics used in the questionnaire included the following: Respondent's designation-supply chain/procurement/logistics manager; others staff (procurement/supply chain or logistics specialists) acting on behalf of their managers. The selected respondents had worked for their organizations for more than three years.

Structured questionnaires were dropped to each organization's procurement, supply chain or logistics department to be filled in by the person in-charge. These were physically picked but with a few sent and received through email. The questionnaire contained four sections: Section A incorporated general organizational profile, while Section B focused on the extent to which ethics was practiced by humanitarian organizations in Kenya. Section $C$ focused on the impact of ethics on procurement performance of humanitarian organizations in Kenya while section $\mathrm{D}$ focused on identifying challenges faced in implementing ethics in humanitarian organizations in Kenya. Data was sorted and coded then entered into the Statistical Package for Social Sciences (SPSS). Descriptive statistics such as means and frequencies were subsequently derived from the analysis. Multiple regression analysis was used to analyze the relationship between the constructs of ethics and procurement performance of humanitarian organizations in Kenya.

\section{Regression Model}

$$
Y=a+b_{1} x_{1}+b_{2} x_{2}+b_{3} x_{3}+b_{4} x_{4}+\cdots+b_{n} x_{n}+\varepsilon
$$

where

$$
\begin{aligned}
& a=\text { Index of ethics unaffected by } X_{1}-X_{8} \\
& \varepsilon=\text { Error term } \\
& Y=\text { Procurement Performance Index } \\
& x_{1}=\text { Competitive Bidding, } x_{2}=\text { Gifts } \\
& X_{3}=\text { Conflict of Interest } \\
& X_{4}=\text { Negotiation } \\
& x_{5}=\text { Reciprocity } \\
& x_{6}=\text { Sharp Practices } \\
& X_{7}=\text { Personal Buying } \\
& x_{8}=\text { Confidentiality }
\end{aligned}
$$

The multiple linear regression function was used to test the relationship between the independent variable and dependent variable in relation to objective 
three. The dependent variable (procurement performance) was measured in response time where respondents were to indicate the amount of time their organizations took to response to an emergency. The findings were presented in percentages and frequency distributions, bar charts, mean and standard deviations.

The organizational profile considered in the study was the respondent's designation, the number of years the organization had been in operation; the current number of employees and respondent's level of education. The results indicate that $68.6 \%$ of the respondents were supply chain/logistics/procurement managers while $31.4 \%$ indicated that the respondents occupied other positions such as procurement officers, procurement advisors, administration secretaries and logistics officers; $51 \%$ of the humanitarian organizations had been operating in Kenya for over 20 years. Similarly, $21.6 \%$ of the humanitarian organizations had been operating in Kenya between 11 and 20 years, while $27.4 \%$ of the organizations had been operating in Kenya in less than 10 years hence the long duration implies that most organizations have a wide experience of using ethics in their procurement processes; $56.9 \%$ of the humanitarian organizations had over 50 employees, $17.6 \%$ of the humanitarian organizations had between 41 50 employees, $11.8 \%$ of the humanitarian organizations had between $31-40$ employees, $5.9 \%$ of the humanitarian organizations had between $21-30$ employees, while only $7.8 \%$ of the humanitarian organizations had less than $20 \mathrm{em}$ ployees. This indicates that most organizations have expanded their operations hence the large size of their workforce; $43.1 \%$ of the employees had a bachelor's degree qualification, $37.3 \%$ of the employees had a master's degree qualification, $17.6 \%$ of the employees had a diploma qualification and only $2 \%$ of the employees had a certificate qualification. This implies that majority of the respondents have a wide knowledge of using ethics in procurement processes.

\section{Impact of Ethics on Procurement Performance}

This study sought to establish the impact of ethics on procurement performance of humanitarian organizations in Kenya. The results of the least square are shown in Table 1 . The established multiple linear regression equation is:

$$
\begin{aligned}
Y= & 1.689+0.534 X_{1}+0.409 X_{2}+0.493 X_{3}+0.507 X_{4} \\
& +0.424 X_{5}+0.413 X_{6}+0.512 X_{7}+0.803 X_{8}
\end{aligned}
$$

The regression equation established that taking all the ethical issues into account constant at zero, procurement performance will be 1.689. The findings presented also show that taking all other independent variables at zero, a unit increase in competitive bidding would lead to a 0.534 increase in procurement performance. Similarly, a unit increase in gifts would lead to a 0.409 increase in procurement performance and so on. The significant values represented by $\mathrm{p}$ are all $<5 \%$ (from 0.013 to 0.031 ) hence this implies that all the predictors used were significant.

The above results concur with the findings of [27] that competitive bidding (with the highest score of 8.215 ) is the ethical and transparent process that 
Table 1. Regressed data.

\begin{tabular}{|c|c|c|c|c|c|}
\hline \multirow[t]{2}{*}{ Model } & \multicolumn{2}{|c|}{$\begin{array}{l}\text { Unstandardized } \\
\text { Coefficients }\end{array}$} & \multirow{2}{*}{$\begin{array}{c}\begin{array}{c}\text { Standardized } \\
\text { Coefficients }\end{array} \\
\text { Beta }\end{array}$} & \multirow[t]{2}{*}{$\mathrm{t}$} & \multirow[t]{2}{*}{ Sig. } \\
\hline & B & Std. Error & & & \\
\hline (Constant) & 1.689 & 0.342 & & 4.939 & 0.013 \\
\hline Competitive Bidding $\left(X_{1}\right)$ & 0.534 & 0.065 & 0.448 & 8.215 & 0.028 \\
\hline Gifts $\left(X_{2}\right)$ & 0.409 & 0.076 & 0.087 & 5.382 & 0.036 \\
\hline Conflict of Interest $\left(X_{3}\right)$ & 0.493 & 0.107 & 0.198 & 4.607 & 0.032 \\
\hline Negotiation $\left(X_{4}\right)$ & 0.507 & 0.097 & 0.243 & 5.227 & 0.039 \\
\hline Reciprocity $\left(X_{5}\right)$ & 0.424 & 0.171 & 0.05 & 2.376 & 0.021 \\
\hline Sharp Practices $\left(X_{6}\right)$ & 0.413 & 0.156 & 0.061 & 2.647 & 0.011 \\
\hline Personal Buying $\left(X_{7}\right)$ & 0.512 & 0.154 & 0.201 & 3.325 & 0.018 \\
\hline Confidentiality $\left(X_{8}\right)$ & 0.803 & 0.275 & 0.256 & 2.920 & 0.031 \\
\hline
\end{tabular}

invites all suppliers to a bid but is hardly followed in the cases of high emergency procurement of aid due to time limitation. To the contrary, reciprocity, which involves giving preference to suppliers in order to influence them to become customers had the lowest score of 2.376 because humanitarian organizations are not profit-oriented hence they would normally not be involved in selling or providing services to customers in exchange for value.

A discussion of the full model irrespective of individual model, Table 2, through the coefficient of determination indicates that $64.5 \%$ of the changes in the procurement performance are attributed to the combined effect of the independent variables which is a good fit.

The probability value of 0.00067 at $95 \%$ confidence level indicates that the regression relationship was significant and that the eight independent variables influenced procurement performance (Table 3 ). The $\mathrm{F}$ calculated at $5 \%$ level of significance was 12.373 (critical value $=2.17$ ), showing that the overall model was significant. The above results concur with the findings of [14] that understanding ethics and its impact on procurement performance is a key responsibility of any supply chain manager. Hence, ethics has a statistically significant relationship with procurement performance. However, a contradiction is found in the studies of [37] that although excellence in companies seems to imply a strong presence of ethical behaviour in those companies, the reverse is not always true, as ethical companies are not necessarily excellent.

\section{Discussion}

The research revealed that there is a positive association between procurement performance and ethical issues. This indicates that when procurement personnel implement ethical policies in their organizations, then procurement performance will also improve. The study also revealed that there is a wide extent of practicing procurement ethics in humanitarian organizations in Kenya. This observation agrees with the findings of [41], who observed that ethics involves 
Table 2. Model summary.

\begin{tabular}{ccccc}
\hline Model & R & R Square & Adjusted R Square & $\begin{array}{c}\text { Std. Error of the } \\
\text { Estimate }\end{array}$ \\
\hline 1 & 0.838 & 0.702 & 0.645 & 0.168 \\
\hline
\end{tabular}

Table 3. Analysis of variance.

\begin{tabular}{ccccccc}
\hline \multicolumn{1}{c}{ Model } & Sum of Squares & df & Mean Square & F & Sig. \\
\hline \multirow{4}{*}{1} & Regression & 3.257 & 8 & 0.407 & 12.373 & 0.00067 \\
& Residual & 1.382 & 42 & 0.033 & & \\
& Total & 4.639 & 50 & & & \\
\hline
\end{tabular}

the concepts of honesty, integrity, probity, diligence, fairness, trust and respect. Similarly, a study by [37] indicated relationship between excellence and ethics.

\section{Limitations and Further Research}

The research was limited by a number of challenges. Firstly, inadequate resources and time to get to different humanitarian organizations located in different parts of the city. Secondly, the respondents were cautious in providing confidential information related to ethical practices. They believed that this could be used against their organizations despite the researcher's assurance to them that responses would be kept confidential. The current study was undertaken in all humanitarian organizations in Kenya and could be replicated in humanitarian organizations in other geographical regions. This could provide a wide range of findings, conclusions and recommendations. Similarly, a study could be conducted by linking the same independent variables to, the other supply chain performance measure, cost reduction in place of response time.

\section{Conclusion}

Ethics is shaping up today's humanitarian picture by ensuring that donors and other interested parties have confidence in supporting the humanitarian cause. By practicing procurement ethics, organizations avoid a litany of unethical issues relating to suppliers. These include: avoidance of conflict of interest, protection of confidential information, maintaining good relationships with suppliers and third parties and avoiding acceptance of gifts, gratuities and hospitality inducements which are likely to compromise procurement decisions. Indeed, ethics in procurement is not only the business of humanitarian organizations but also the globalization of markets which is pressurizing companies to develop codes as public statements of core principles that are universally applicable [42]. This study will be beneficial to all stakeholders interested in humanitarian response. Supply chains that incorporate ethics to operations would make better use of resources, matching available supplies with the highest priority needs in the shortest time possible under the constraint of limited funding. The donors should have confidence in humanitarian organizations because they are assured aid is 
not misused in ethical humanitarian entities. Moreover, the beneficiaries who are the victims of disasters could learn from what to expect of the humanitarian relief operations and have hope in getting both assisted as well as sustained. Lastly, this study is beneficial to researchers because it provides valuable information in supply chain management theory.

\section{References}

[1] Van Wassenhove, L.N. (2006) Humanitarian Aid Logistics: Supply Chain Management in High Gear. Journal of the Operational Research Society, 57, 475-489. https://doi.org/10.1057/palgrave.jors.2602125

[2] Guha-Sapir, D., Vos, F., Below, R. and Ponserre, S. (2012) Annual Disaster Statistical Review 2011: The Numbers and Trends. Published by the Centre for Research on the Epidemiology of Disasters (CRED), Brussels.

[3] Nyamu, T. (2012) Impact of Supply Chain Management Challenges on Humanitarian Organizations in Kenya. Project Research presented to the University of Nairobi, School of Business, Nairobi.

[4] Benita, M.B. and Burcu, B. (2008) Performance Measurement in Humanitarian Relief Chains. International Journal of Public Sector Management, 21, 4-25. https://doi.org/10.1108/09513550810846087

[5] Heaslip, G. and Barber, E. (2014) Using the Military in Disaster Relief: Systemizing Challenges and Opportunities. Journal of Humanitarian Logistics and Supply Chain Management, 4, 60-81. https://doi.org/10.1108/JHLSCM-03-2013-0013

[6] Rolando, T. and Wassenhove, L.V. (2009) Humanitarian Logistics. Macmillan Publishers Limited, Hampshire, Palgrave.

[7] Van Weele, A.J. (2002) Purchasing and Supply Chain Management. Analysis, Planning and Practice. 3rd Edition, Thomson Learning, London.

[8] Amaratunga, D. and Baldry, D. (2002) Moving from Performance Measurement to Performance Management. Facilities, 20, 217-223. https://doi.org/10.1108/02632770210426701

[9] Adams, F.K. (2008) Construction Contract Risk Management. A Study of Practices in the United Kingdom. Cost Engineering, 50, 22-23.

[10] Lysons, K. and Farrington, B. (2012) Purchasing and Supply Chain Management. Pearson Education Limited, England.

[11] Pedersen, E.R. (2009) The Many and Few: Rounding up the SMEs that Manage CSR in the Supply Chain. Supply Chain Management. An International Journal, 2, 109-116. https://doi.org/10.1108/13598540910941975

[12] Carter, C.R. (2005) Purchasing Social Responsibility and Firm Performance: The Key Mediating Roles of Organizational Learning and Supply Performance. International Journal of Physical Distribution \& Logistics Management, 35, 177-194. https://doi.org/10.1108/09600030510594567

[13] Wagner, S.M. (2003) Intensity and Managerial Scope of Supplier Integration. Journal of Supply Chain Management, 39, 4-13. https://doi.org/10.1111/j.1745-493X.2003.tb00160.x

[14] Eltantawy, R.A., Fox, G.L. and Guinipero, L. (2009) Supply Management Ethical Responsibility: Reputation and Performance Impacts. An International Journal, 14, 99-108.

[15] Cooper, R.W., Frank, G.L. and Kemp, R.A. (1997) The Ethical Environment Facing 
the Profession of Purchasing and Materials Management. International Journal of Purchasing and Materials Management, 33, 2-13. https://doi.org/10.1111/j.1745-493X.1997.tb00286.x

[16] Flech, R.I. (1985) Standards of Conduct: The Key to Supplier Relations. Journal of Purchasing and Materials Management, 21, 16-18. https://doi.org/10.1111/j.1745-493X.1985.tb00137.x

[17] Carter, C.R. and Jennings, S.M. (2004) The Role of Purchasing in Corporate Social Responsibility: A Structural Equation Analysis. Journal of Business Logistics, 25, 145-188. https://doi.org/10.1002/j.2158-1592.2004.tb00173.x

[18] Giunipero, L. and Handfield, R.B. (2004) Purchasing Education and Training II. CAPS Research, Tempe.

[19] Callaghan, P. (2009) Procurement Ethics. Journal of Purchasing, 28, 233-237.

[20] McWilliams, A. and Siegel, D. (2000) Corporate Social Responsibility and Financial Performance. Strategic Management Journal, 21, 603-609. https://doi.org/10.1002/(SICI)1097-0266(200005)21:5<603::AID-SMJ101>3.0.CO;2$\underline{3}$

[21] Onyango, J.P. (2012) Role of Ethics in Supply Chain Management of Oil Marketing Firms in Kenya. Project Research Presented to the University of Nairobi, School of Business, Nairobi.

[22] Slack, N., Chambers, S. and Johnston, R. (2004) Operations Management. Pearson Education Limited, Harlow.

[23] Wild, N. and Zhou, L. (2011) Ethical Procurement Strategies for International Aid Non-Government Organizations. Supply Chain Management. An International Journal, 16, 110-127. https://doi.org/10.1108/13598541111115365

[24] Oloruntoba, R. and Gray, R. (2006) Humanitarian Aid: An Agile Supply Chain. Supply Chain Management. An International Journal, 1, 115-120. https://doi.org/10.1108/13598540610652492

[25] Turner, G.B., Taylor, G.S. and Hartley, M.F. (1994) Ethics Policies and Gratuity Acceptance by Purchasers. International Journal of Purchasing and Materials Management, 30, 43-47. https://doi.org/10.1111/j.1745-493X.1994.tb00196.x

[26] Svensson, G. (2009) The Transparency of SCM Ethics: Conceptual Framework and Empirical Illustrations. Supply Chain Management. An International Journal, 4, 259-269. https://doi.org/10.1108/13598540910970090

[27] Balcik, B. and Beamon, B.M. (2008) Facility Location in Humanitarian Relief. International Journal of Logistics-Research and Applications, 11, 101-121. https://doi.org/10.1080/13675560701561789

[28] Taupiac, C. (2001) Humanitarian and Development Procurement: A Vast and Growing Market. International Trade Forum, 4, 7-10.

[29] Jessica, S. and Tina, S. (2008) Disasters: Corruption in Emergency Procurement. Overseas Development Institute, 32, 516-536.

[30] Leenders, M.R., Johnston, P.F., Flynn, A.E. and Fearon, H.E. (2010) Purchasing and Supply Chain Management: With 50 Supply Chain Cases. Tata McGraw Hill Education Private Limited, New Delhi.

[31] Christian, P. (2011) Preventing Corruption in Humanitarian Operations. Transparency International: Norwegian Red Cross.

[32] Steinbuch, P.A. (2001) Logistik. Neue Wirtschafts-Briefe, Berlin/Herne.

[33] Handfield, R.B., Monczka, R.M., Giunipero, L.C. and Patterson, J.L. (2011) Sourc- 
ing and Supply Chain Management. Cengage Learning Products, New Delhi.

[34] Micheli, P. and Kennerly, M. (2005) Performance Measurement Frameworks in Public and Non-Profit Sectors. Production Planning and Control, 16, 125-134. https://doi.org/10.1080/09537280512331333039

[35] Poister, T.H. (2003) Measuring Performance in Public and Non-Profit Organizations. Jossey-Bass, San Francisco.

[36] Deephouse, D.L. (2000) Media Reputation as a Strategic Resource: An Integration of Mass Communication and Resource-Based Theories. Journal of Management, 26, 1091-1112. https://doi.org/10.1177/014920630002600602

[37] Van Der Merwe, R., Pitt, L.F. and Berthon, P. (2003) Are Excellent Companies Ethical? Evidence from an Industrial Setting. Corporate Reputation Review, 5, 343-355. https://doi.org/10.1057/palgrave.crr.1540183

[38] Michael, B. and Rusell, A. (2007) Corporate Identity, Ethics and Reputation in Supplier-Buyer Relationships. Journal of Business Ethics, 76, 69-82. https://doi.org/10.1007/s10551-006-9273-4

[39] Ndolo, J. and Njagi, E. (2014) Role of Ethics in Procurement Process Effectiveness in the Water Sector in Kenya: A Case Study of EWASCO, Embu County. Project Research Presented to Mount Kenya University, School of Business and Economics, Thika.

[40] Mbae, L.N. (2014) Public Procurement Law and Procurement Performance of County Governments in Kenya: A Case of Machakos County Government. Project Research Presented to the University of Nairobi, School of Business, Nairobi.

[41] Kleinberg-Levin, D.M. (2008) Before the Voice of Reason: Echoes of Responsibility in Merleau-Ponty's Ecology and Levinas's Ethics. SUNY Press, New York.

[42] Carasco, E.F. and Singh, J.B. (2003) The Content and Focus of the Codes of Ethics of the World's Largest Transnational Corporations. Business and Society Review, 108, 71-94. https://doi.org/10.1111/1467-8594.00007 


\section{Appendix: Questionnaire}

\section{Introduction}

This questionnaire has been designed for academic use only. It aims to establish the impact of ethics on procurement performance of humanitarian organizations in Kenya.

Please note that the data that you provide will be handled with utmost confidentiality and privacy. Thank you for your consideration.

\section{Section A: General Information}

Answer the following questions by ticking alongside your choice.

1) What is your position in this organization?

a) Supply Chain Manager/Logistics Manager/Procurement Manager

b) Others (please specify)

2) How long has your organization been in operation in Kenya?
Below 5 years
5 - 10 years
11 - 20 years
over 20 years

3) What is the current number of employees in your organization?
Below 20
$21-30$
$31-40$
$41-50$
over 50

4) What is the level of your education?

\section{Certificate $\square \quad$ Diploma $\square \quad$ Bachelor's Degree $\square \quad$ Master's Degree $\mathrm{PhD}$}

Section B: Extent to which Ethics is practised in Humanitarian Organizations in Kenya

Please indicate the extent to which you concur with the following statements on the extent of practising procurement ethics in your organization's procurement process.

Use the scale of: $1=$ very large extent $2=$ large extent $3=$ moderate extent $4=$ small extent 5 = very small extent.

\begin{tabular}{|c|c|c|c|c|c|c|}
\hline No & Statement & 1 & 2 & 3 & 4 & 5 \\
\hline 1. & $\begin{array}{l}\text { The organization makes it obligatory for all suppliers } \\
\text { bidding in a procurement process to sign an ethics } \\
\text { statement committing them to behave with integrity. }\end{array}$ & & & & & \\
\hline 2. & Ethical violation of bid rigging is prohibited. & & & & & \\
\hline 3. & Ethical violation of bid collusion is prohibited. & & & & & \\
\hline 4. & $\begin{array}{l}\text { The organization has a zero tolerance to } \\
\text { giving gifts of any kind. }\end{array}$ & & & & & \\
\hline 5. & $\begin{array}{l}\text { The organization has a zero tolerance to } \\
\text { acceptance of gifts of any kind. }\end{array}$ & & & & & \\
\hline 6. & $\begin{array}{l}\text { There exists a limited nominal value to } \\
\text { which gifts should not be exceeded. }\end{array}$ & & & & & \\
\hline 7. & $\begin{array}{l}\text { All procurement personnel are required to disclose any } \\
\text { economic or other shared interest with a third party } \\
\text { (family, emotional life, political or national affinity, } \\
\text { economic interest). }\end{array}$ & & & & & \\
\hline 8. & $\begin{array}{l}\text { Negotiation takes place only in the } \\
\text { cases of single-source situation. }\end{array}$ & & & & & \\
\hline
\end{tabular}




\section{Continued}

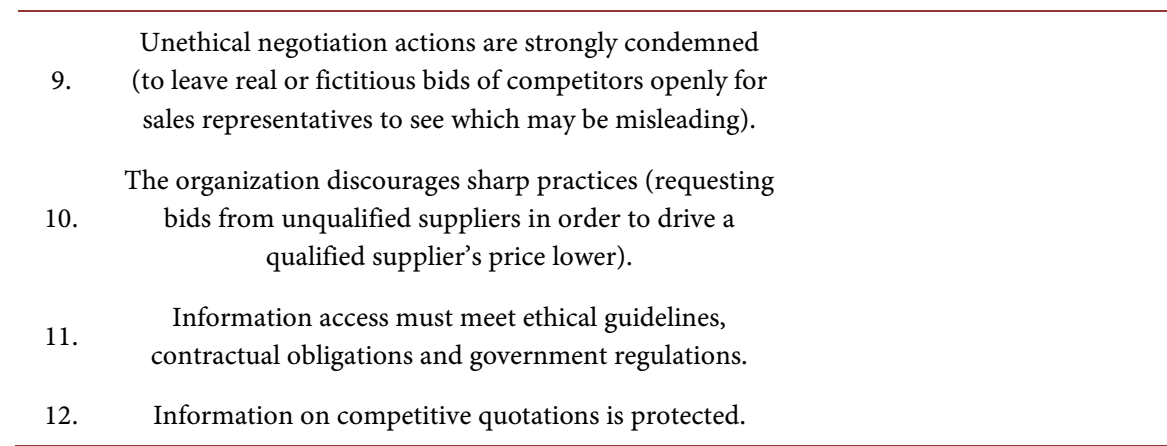

\section{Section C 1): Impact of Ethics on Procurement Performance}

Please indicate the extent to which you concur with the following statements on the impact of procurement ethics on supply chain performance.

Use the scale of: $1=$ very large extent $2=$ large extent $3=$ moderate extent $4=$ small extent 5 = very small extent.

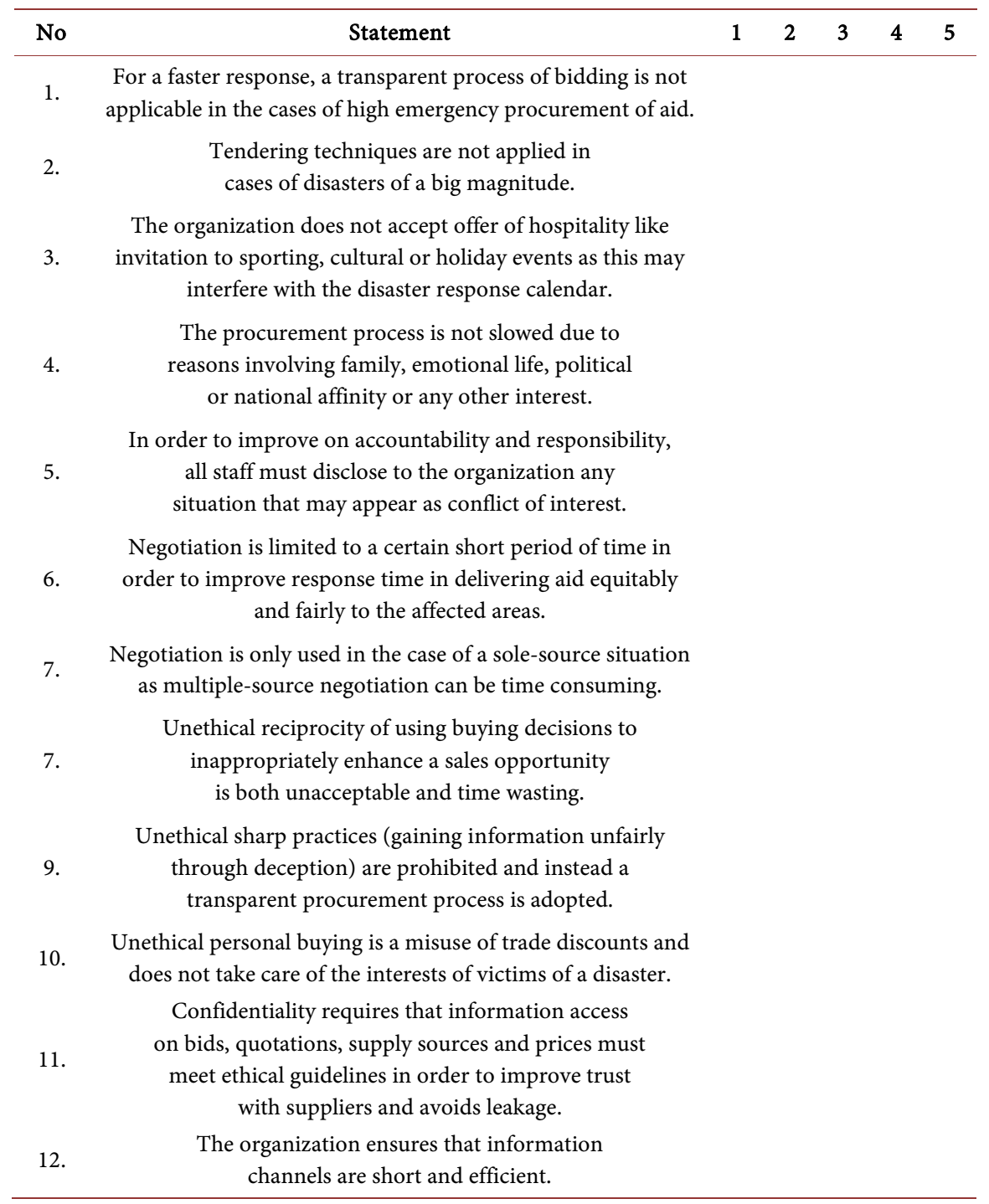




\section{2): Performance Measurement}

Please indicate the span of response time your organization usually takes in the case of a disaster. Use the scale of 0 - 5 hours, 6 - 10 hours, 11 - 15 hours, 16 20 hours and above 20 hours.

\begin{tabular}{lccc}
\hline No & Statement & $0-56-1011-15 \quad 16-20$ & $>\mathbf{2 0}$ \\
\hline 13. & $\begin{array}{l}\text { Indicate the average response time in hours your } \\
\text { organization takes in the case of an emergency. }\end{array}$ \\
\hline
\end{tabular}

\section{Section D: Challenges of Implementing Procurement Ethics}

Please indicate the extent to which you agree with the following statements on challenges of implementing ethics in humanitarian organizations.

Use the scale of: $1=$ strongly disagree $2=$ disagree $3=$ neutral $4=$ agree $5=$ strongly agree.

\begin{tabular}{|c|c|c|c|c|c|c|}
\hline No & Statement & 1 & 2 & 3 & 4 & 5 \\
\hline 1. & $\begin{array}{l}\text { Most people perceive ethical codes as being remote from } \\
\text { the real world (are not applicable in reality). }\end{array}$ & & & & & \\
\hline 2. & $\begin{array}{l}\text { Communication barrier deters implementation of } \\
\text { ethical behaviour hence it is difficult to get foreign } \\
\text { suppliers sign a code of ethics. }\end{array}$ & & & & & \\
\hline 3. & $\begin{array}{l}\text { Culture remains an ethical dilemma in } \\
\text { providing aid to civilians. }\end{array}$ & & & & & \\
\hline 4. & $\begin{array}{l}\text { Moral muteness makes managers opt to remain } \\
\text { quiet than speak out in situations where they } \\
\text { disagree with work circumstances. }\end{array}$ & & & & & \\
\hline 5. & Corruption is an impediment to instituting a code of ethics. & & & & & \\
\hline 6. & $\begin{array}{l}\text { Political pressure deters the implementation } \\
\text { of ethical behaviour. }\end{array}$ & & & & & \\
\hline 7. & $\begin{array}{l}\text { One's level of education determines the } \\
\text { understanding and practicing of ethical behaviour. }\end{array}$ & & & & & \\
\hline 8. & $\begin{array}{l}\text { The urgency and severity of a disaster may } \\
\text { overlook ethical behaviour. }\end{array}$ & & & & & \\
\hline 9. & $\begin{array}{l}\text { There is no clarity as to whom the } \\
\text { duty of ethics is accountable. }\end{array}$ & & & & & \\
\hline 10. & $\begin{array}{l}\text { Ethics is relative, as what is ethical in one } \\
\text { organization may be unethical in another. }\end{array}$ & & & & & \\
\hline
\end{tabular}

Others 